INFLAMMATORY BOWEL DISEASE

\title{
A randomised placebo controlled trial of pegylated interferon $\alpha$ in active ulcerative colitis
}

\author{
H Tilg, H Vogelsang, O Ludwiczek, H Lochs, A Kaser, J-F Colombel, H Ulmer, P Rutgeerts, \\ S Krüger, A Cortot, G D’Haens, M Harrer, C Gasche, F Wrba, I Kuhn, W Reinisch
}

Gut 2003;52:1728-1733

See end of article for authors' affiliations

Correspondence to:

Correspondence to:
Dr H Tilg, Department of Medicine, Division of Gastroenterology and Hepatology, University Hospital Innsbruck,

Anichstrasse 35, 6020

Innsbruck, Austria;

Herbert.Tilg@uibk.ac.at

Accepted for publication 1 July 2003
Background: Pilot studies of interferon $\alpha$ (IFN- $\alpha$ ) suggest a high remission rate in the treatment of active ulcerative colitis. We evaluated the safety of pegylated interferon $\alpha$ (PegIFN) and its role in induction of remission in patients with active ulcerative colitis, in a multicentre placebo controlled trial.

Methods: Sixty patients with a clinical activity score (CAl) of $>6$ were randomised to receive placebo $(\mathrm{n}=20)$, PegIFN $0.5 \mu \mathrm{g} / \mathrm{kg}(\mathrm{n}=19)$, or PegIFN $1.0 \mu \mathrm{g} / \mathrm{kg}$ body weight $(\mathrm{n}=21)$ once weekly (Peglntron; Schering-Plough, USA) over 12 weeks. Patients receiving 5-aminosalicylates, steroids, and/or azathioprine in stable dosages were included.

Results: Serious adverse events were seen in none of the placebo patients, in 3/19 patients in the PegIFN $0.5 \mu \mathrm{g} / \mathrm{kg}$ group (hospitalisation due to disease flare up $\mathrm{n}=3$ ), and in $3 / 21$ in the PeglFN $1.0 \mu \mathrm{g} / \mathrm{kg}$ group (hospitalisation due to disease flare up $n=1$; thrombosis $n=1$; grand mal seizure $n=1$ ). Otherwise, we observed only minor IFN- $\alpha$ side effects. Clinical remission rates at week 12 (CAl $\leqslant 4$ ) were $7 / 20$ (35\%) in the placebo, $9 / 19(47 \%)$ in the PegIFN $0.5 \mu \mathrm{g} / \mathrm{kg}$ group, and $7 / 21(33 \%)$ in the PegIFN $1.0 \mu \mathrm{g} / \mathrm{kg}$ group (NS). Early withdrawal from the study was observed in $11 / 20$ placebo patients, in $6 / 19$ in the PegIFN $0.5 \mu \mathrm{g} / \mathrm{kg}$ group, and in 10/21 in the PegIFN $1.0 \mu \mathrm{g} / \mathrm{kg}$ group, mainly due to lack of efficacy. The higher PegIFN dose was associated with a significant decrease in levels of $\mathrm{C}$ reactive protein $(p=0.003$, day $0 \vee 85)$.

Conclusions: PegIFN is safe but not effective, at the dosages used, in patients with ulcerative colitis.
U cerative colitis (UC) is a relapsing chronic inflammatory disorder of the colon of unknown cause in which immunological, environmental, and to some degree genetic influences may be involved. ${ }^{12}$ It has also been postulated that UC may be caused by infection because there are common histological features with infectious colitis and it is difficult to induce colonic inflammation in germ free animals. Treatment is accordingly unspecific, mostly based on the anti-inflammatory agents 5-aminosalicylate and glucocorticosteroids, and a significant proportion of patients require immunosuppressive treatment and/or colectomy. ${ }^{12}$ This has led in the last years to a search for alternative therapeutic options to improve the current medical treatment of the disease.

Mediators of the immune system are fundamentally involved in the regulation of chronic inflammation. It is commonly believed that the cytokine milieu and the predominant $\mathrm{T}$ helper cell phenotype (Th) critically affect the phenotype of chronic inflammation in the gut, leading to the assumption that Crohn's disease is a more Thl and UC a more Th2 linked disease. ${ }^{3}{ }^{4}$ There is increasing evidence that interferon $\alpha($ IFN- $\alpha)$ interferes with the synthesis of various cytokines and in some cases acts as an anti-inflammatory agent. ${ }^{56}$ Apart from its potency to induce anti-inflammatory cytokines such as interleukin 1 receptor antagonist (IL-1Ra) and/or soluble tumour necrosis factor receptor p55 (TNFsR), ${ }^{78}$ IFN- $\alpha$ regulates and downmodulates Th2 cytokines such as interleukin (IL)-5 and IL-13, ${ }^{10}$ which have been shown to be upregulated in UC. ${ }^{11}{ }^{12}$ These in vitro effects are paralleled by various in vivo findings suggesting that IFN$\alpha$ may worsen Th- 1 linked diseases such as psoriasis and arthritis. ${ }^{6}$ Furthermore, pilot studies initiated with conventional IFN- $\alpha$ suggested a beneficial effect of this cytokine in the treatment of UC..$^{13}$ Sumer and Palabiyikoglu initially reported that more than $80 \%$ of patients with active UC responded to IFN- $\alpha$ therapy and were in complete clinical and endoscopic remission after six months of therapy. ${ }^{13}$ Twenty six of 28 IFN treated patients were observed for more than two years without being given therapy, and remained in full clinical and endoscopic remission. Another report recently published by Madsen et al demonstrated a similar degree of efficacy of IFN- $\alpha$ in active left sided UC. ${ }^{14}$

The above in vitro findings together with the first positive clinical results indicated that a randomised controlled trial using IFN- $\alpha$ for the treatment of active UC was warranted. We have undertaken a double blind randomised study to determine as our primary objective the safety of pegylated IFN- $\alpha$ (PegIFN) and as our secondary objective the efficacy of PegIFN, in patients with active UC over a 12 week treatment period.

\section{MATERIALS AND METHODS Study design}

This study was conducted in five university hospitals in Austria, Germany, France, and Belgium. A randomised, multicentre, placebo controlled study was carried out, investigating the role of PegIFN ( 0.5 and $1.0 \mu \mathrm{g} / \mathrm{kg}$ body weight) in patients with active UC. Our primary objective was to assess the safety and tolerance of PegIFN in UC patients. Secondary objectives were to define the effects of PegIFN on disease activity (assessed by the Rachmilewitz clinical activity score $\left.(\mathrm{CAI})^{15}\right)$, endoscopic activity (Rachmilewitz endsocopy

Abbreviations: IFN- $\alpha$, interferon $\alpha$; PegIFN, pegylated interferon $\alpha$; UC, ulcerative colitis; CAl, clinical activity score; Th, T helper; IL, interleukin; IL-1Ra, interleukin 1 receptor antagonist; TNF- $\alpha$, tumour necrosis factor $\alpha$; TNFsR, tumour necrosis factor receptor $\mathrm{p} 55$; CRP, C reactive protein; AGP, alpha-1 acid glycoprotein 
score $^{15}$ ), and serum inflammatory markers (C reactive protein (CRP); alpha- 1 acid glycoprotein (AGP)).

\section{Patient population}

Sixty consecutive patients with exacerbation of UC were asked for written informed consent to take part in this study. The study was approved by the local research ethics committees. Eligible patients were aged 18 years or older with a documented diagnosis of UC ( $>6$ months) who had been in remission while receiving oral and local 5-aminosalicylate maintenance therapy ( $2 \mathrm{~g}$ orally or more) and who had experienced a flare in disease. 5-Aminosalicylate therapy had to be taken for at least eight weeks prior to initiation of the study and topical 5-aminosalicylate therapy had to be discontinued one week before administration of the study medication. Furthermore, we included patients showing clinical activity despite stable doses of steroids and/or azathioprine (at least six months of treatment). The patient must have had received oral prednisone (10-40 mg/day) or equivalent doses of prednisolone or methylprednisone for at least two weeks at a stable dose prior to study drug administration without a decrease in CAI. The steroid dose was kept stable during the first four weeks of the treatment phase; thereafter tapering was allowed if CAI was $<4$.

Active disease was defined by a Rachmilewitz index of $>6$, defined as four or more liquid stools a day for the last seven days, and only patients with blood in stool were included. Patients with an immediate need for surgery or requiring parenteral steroids, those with severe anaemia defined as a haemoglobin level $<10 \mathrm{~g} / \mathrm{dl}$, pregnancy, and infection due to enteric pathogens, pathogenic ova, parasites, or Clostridium difficile toxin were excluded. All patients underwent screening sigmoidoscopy and/or colonoscopy prior to the start of treatment (day -1 ) and thereafter on days +29 and +85 (therapy end). Endoscopic activity was assessed by the Rachmilewitz endoscopy score and active disease was defined as a score $>4 .^{15}$

\section{Drugs and dosing}

At entry, all patients were randomised to receive placebo, PegIFN $0.5 \mu \mathrm{g} / \mathrm{kg}$, or PegIFN $1.0 \mu \mathrm{g} / \mathrm{kg}$ body weight. The drugs were administered subcutaneously over a treatment period of 12 weeks once weekly. Patients not achieving remission within four weeks were offered additional treatment, including steroids and/or immunosuppressive treatment. Remission was defined as a Rachmilewitz index $\leqslant 4$. $^{15}$ Endosocopic remission was defined as a score of $<4$.

\section{Assessments}

At baseline, a medical history was taken, and a full physical examination with assessment of symptoms was performed. Patients were evaluated pretreatment (day -8$)$, and on days $0,+8,+15,+29,+43,+57$, and +85 . Clinical activity scores (Rachmilewitz) and laboratory results were obtained at these time points. The following laboratory parameters were measured: haemoglobin, white cell count, platelet count, CRP, AGP, creatinine, liver function tests, and albumin. Laboratory analyses were performed locally at each study centre. Sigmoidoscopy/colonosocpy and biopsies from various parts of the colon, including the rectum, were performed on days $0,+29$, and +85 . Sigmoidoscopy/colonoscopy was graded according to the Rachmilewitz endoscopy activity index, and biopsy/histology was graded from 0 to 3 on the basis of a previously graded scale. ${ }^{16}$ Only rectal biopsies were used for histological analysis and were available on day 0 in 26/60 study patients, on day+29 in 16, and on day+85 in nine study patients. Biopsy samples were available from one study centre and were assessed by a single pathologist (FW) in a blinded manner. In the follow up observation period, patients were seen at weeks 12 and 26.

\section{End points}

The primary end point of the study was safety. All adverse events were recorded systemically and classified as those deemed to be serious or non-serious and likely or unlikely to be related to treatment. Secondary analyses were performed on definite improvement of CAI (number of patients in remission at week 12 as defined by a CAI $\leqslant 4$ ), absolute sigmoidoscopic score (Rachmilewitz endoscopy score $<4$ at week 12), histological activity in a subgroup of patients (rectal histology at week 12), and changes in serological inflammatory indices during treatment.

\section{Statistical analysis}

Baseline comparability of study groups regarding patient age and sex, duration of disease, and other disease related variables and study centre was evaluated using analysis of variance or Kruskal-Wallis tests for continuous variables and $\chi^{2}$ tests for categorical variables.

Because of the rather frequent number of dropouts during the study, a mixed effects regression analysis was employed to make full use of all of the measurements, to analyse differences in the Rachmilewitz score and in other laboratory parameters between study groups. Variables which did not meet the assumption of normality were logarithmically transformed. Continuous variables are given as means (SD) and categorical variables as frequencies and percentages. A $\mathrm{p}$ value of $<0.05$ was considered to indicate statistical significance. Due to the pilot character of the study, no corrections for multiple comparisons were applied. Rate of relapsers was analysed by the Fisher's exact test.

A placebo response rate of $30 \%$ may be expected for patients with active UC. In the case of efficacy, PegIFN therapy should result in a response rate of approximately $60 \%$ to compete with standard treatments. Sample size calculations showed that 60 patients (20 patients in each treatment group) were needed to show a difference of $51 \%$ with $95 \%$ confidence and $80 \%$ power.

\section{RESULTS}

Sixty consecutive patients were randomised in this multicentre placebo controlled trial. Population demographics and disease characteristics are given in table 1. These characteristics were similar in all three treatment groups. Twenty eight of 60 patients had received steroid and/or azathioprine therapy at study entry.

\section{Serious adverse events}

The primary objective of our trial was the effect of PegIFN treatment on tolerability in this patient group. We observed no serious adverse events in the placebo group. In contrast, in the PegIFN $0.5 \mu \mathrm{g} / \mathrm{kg}$ and $1.0 \mu \mathrm{g} / \mathrm{kg}$ groups, we observed three serious adverse events at each dose level. All three serious adverse events in the lower IFN group were due to lack of efficacy and all patients required hospitalisation and intensification of treatment (in two patients at week 2 and in one patient at week 3 of the study). In the PegIFN $1.0 \mu \mathrm{g} / \mathrm{kg}$ group, the following three serious adverse events were observed: one patient required hospitalisation due to disease flare up at week 3 of the study; one patient developed a thrombosis of the vena brachiocephalica after the first injection of study drug after withdrawal of a central vein catheter; and the third patient developed a grand mal seizure at week 8 of the study. All serious adverse events resolved without any complications or life threatening aspects to the patients. 
Table 1 Patient characteristics at screening examination in the placebo and pegylated interferon $\alpha$ (PeglFN) groups

\begin{tabular}{|c|c|c|c|c|}
\hline & \multicolumn{2}{|l|}{ PegIFN } & \multirow[b]{2}{*}{ Placebo $(n=20)$} & \multirow[b]{2}{*}{ p Value } \\
\hline & $\begin{array}{l}0.5 \mu \mathrm{g} / \mathrm{kg} \\
(\mathrm{n}=19)\end{array}$ & $\begin{array}{l}1 \mu \mathrm{g} / \mathrm{kg} \\
(\mathrm{n}=21)\end{array}$ & & \\
\hline Sex & & & & 0.985 \\
\hline Males (n (\%)) & $9(47.0)$ & $11(52.4)$ & $10(50.0)$ & \\
\hline Females (n (\%)) & $10(53.0)$ & $10(47.6)$ & $10(50.0)$ & \\
\hline Age (months) & $36.90(13.19)$ & $40.90(10.84)$ & $46.95(14.43)$ & 0.053 \\
\hline Weight (kg) & 68.38 (12.48) & 70.00 (13.31) & $71.82(17.39)$ & 0.756 \\
\hline Duration of disease (months) & $107.3(64.11)$ & $106.88(71.83)$ & $142.90(132.01)$ & 0.867 \\
\hline Prestudy steroid therapy (n (\%)) & $6(31.6)$ & $9(42.9)$ & $5(25.0)$ & 0.452 \\
\hline Prestudy azathioprine therapy (n (\%)) & $2(10.5)$ & $3(14.3)$ & $3(15.0)$ & 0.879 \\
\hline Prestudy 5-ASA therapy (n (\%)) & 15 (78.9) & $19(90.5)$ & $15(75.0)$ & 0.325 \\
\hline Topical 5-ASA treatment & $4(21.1)$ & $2(9.5)$ & $3(15.0)$ & 0.639 \\
\hline Localisation of inflammation & & & & 0.604 \\
\hline Sinistral (n (\%)) & $13(68.4)$ & $12(57.1)$ & $14(70.0)$ & \\
\hline Pancolitis (n (\%)) & $6(31.6)$ & $9(42.9)$ & $6(30.0)$ & \\
\hline
\end{tabular}

\section{Frequently occurring side effects}

One patient in the placebo group and two patients in the PegIFN $1.0 \mu \mathrm{g} / \mathrm{kg}$ group finished the trial early due to side effects (placebo group, fever; PegIFN $1.0 \mu \mathrm{g} / \mathrm{kg}$ group, two serious adverse events). Side effects were altogether minor and details are given in table 2. As expected, the most common side effects were anaemia, leukopenia, fever, flulike symptoms, headache, and erythema at the injection site.

\section{Clinical end points}

After 12 weeks of treatment, there was no statistically significant difference between the rate of remission (CAI $\leqslant 4)$ in the two PegIFN groups $(0.5 \mu \mathrm{g} / \mathrm{kg}, \mathrm{n}=19 ; 1.0 \mu \mathrm{g} / \mathrm{kg}$, $\mathrm{n}=21$ ) and the placebo group $(\mathrm{n}=20)$ (for details see table 3 and fig 1). Whereas the highest remission rate for both PegIFN groups was observed at week 12, the highest remission rate in the placebo group was already seen at week 4 . The highest remission rate at week 12 was seen in the $0.5 \mu \mathrm{g} / \mathrm{kg}$ group $(9 / 19 ; 47 \%)$. The highest dropout rate was observed in the placebo group $(11 / 20 ; 55 \%)$ whereas the lowest dropout rate was seen in the $0.5 \mu \mathrm{g} / \mathrm{kg}$ PegIFN group $(6 / 19 ; 32 \%)$. Reasons for early withdrawal were mostly insufficient therapeutic effects of treatment (placebo group 10/20; PegIFN $0.5 \mu \mathrm{g} / \mathrm{kg}$ group 6/19; PegIFN $1.0 \mu \mathrm{g} / \mathrm{kg}$ group $8 / 21$ ). One patient in the placebo group, one in the PegIFN $0.5 \mu \mathrm{g} / \mathrm{kg}$ group, and three in the PegIFN $1.0 \mu \mathrm{g} / \mathrm{kg}$ group were able to taper and withdraw steroids in the 12 week treatment period. Underlying treatment of UC (either 5aminosalicylate, steroids, or azathioprine) had no effect on the likelihood of achieving clinical remission during treatment up to week 12 (data not shown).

\section{Endoscopic and histological endpoints}

On day $+85,9 / 20$ patients in the placebo group, 11/19 in the PegIFN $0.5 \mu \mathrm{g} / \mathrm{kg}$ group, and $10 / 21$ in the PegIFN $1.0 \mu \mathrm{g} / \mathrm{kg}$ group underwent endoscopy. Details are presented in table 3 and fig 2 . There was no difference with respect to endoscopic activity at any time point between the three treatment groups. The highest rate of endoscopic remission was seen both on days +29 and +85 in the placebo group. There was however a rather weak correlation between CAI and endoscopic activity index $(r=0.55)$. In a subgroup of patients (day $0, \mathrm{n}=26$; day $29, \mathrm{n}=16$; day $85, \mathrm{n}=9$ ) we were able to assess rectal histological activity. There was no difference between the three treatment groups pretreatment and on day +29 (placebo 3.1 (2.5) v 3.6 (2.2); PegIFN $0.5 \mu \mathrm{g} / \mathrm{kg} 5.9$ (1.5) $v$ 5.9 (1.1); PegIFN $1.0 \mu \mathrm{g} / \mathrm{kg} 6.4$ (1.4) $v 6.0(1.4)$ ). Data on day +85 were too limited to allow comparison.

\section{Serum inflammatory parameters (CRP, AGP)}

Details of laboratory parameters are presented in table 4 . There was a dose dependent decrease in haemoglobin and

\begin{tabular}{|c|c|c|c|}
\hline Adverse event & Placebo & PeglFN $0.5 \mu \mathrm{g} / \mathrm{kg}$ & PegIFN $1 \mu \mathrm{g} / \mathrm{kg}$ \\
\hline \multicolumn{4}{|l|}{ Haematological } \\
\hline Anamia & 3 & 2 & 7 \\
\hline Leukopenia & 2 & 3 & 4 \\
\hline Thrombocytopenia & 0 & 0 & 0 \\
\hline \multicolumn{4}{|l|}{ Hepatic } \\
\hline Elevation of bilirubin & 0 & 0 & 0 \\
\hline \multicolumn{4}{|l|}{ Gastrointestinal } \\
\hline Nausea & 1 & 2 & 3 \\
\hline Pancreatitis & 1 & 0 & 0 \\
\hline Fever & 2 & 8 & 7 \\
\hline Erythema at injection site & 0 & 10 & 5 \\
\hline Flu-like symptoms & 2 & 11 & 11 \\
\hline Hair loss & 1 & 1 & 4 \\
\hline \multicolumn{4}{|l|}{ Infections } \\
\hline $\begin{array}{l}\text { Minor infection } \\
\text { Major infection }\end{array}$ & 0 & 0 & $\begin{array}{l}0 \\
0\end{array}$ \\
\hline Headache & 0 & 7 & 4 \\
\hline
\end{tabular}


Table 3 Mean clinical activity index/endoscopic activity during 12 weeks of treatment with placebo or pegylated interferon $\alpha$ (PeglFN)

\begin{tabular}{|c|c|c|c|c|c|c|c|c|}
\hline & Day 0 & Day 8 & Day 15 & Day 29 & Day 43 & Day 57 & Day 85 & $\begin{array}{l}\text { Patients on day } \\
0 / 85\end{array}$ \\
\hline \multicolumn{9}{|l|}{ PegIFN $0.5 \mu \mathrm{g} / \mathrm{kg}(\mathrm{n}=19)$} \\
\hline Rachmilewitz & $8.0(2.1)$ & $7.3(3.0)$ & $6.4(3.2)$ & $4.9(2.9)$ & $4.3(2.8)$ & $4.1(2.8)$ & $3.1(2.5)$ & $n=19 / 13$ \\
\hline Endoscopic index & $8.3(2.1)$ & & & $5.8(4.0)$ & & & $5.1(4.1)$ & $n=19 / 11$ \\
\hline No of patients treated & 19 & 19 & 18 & 15 & 14 & 13 & 13 & \\
\hline No of patients in remission & 0 & 2 & 2 & 6 & 8 & 7 & 9 & \\
\hline \multicolumn{9}{|l|}{ PegIFN $1 \mu \mathrm{g} / \mathrm{kg}(\mathrm{n}=21)$} \\
\hline Rachmilewitz & $7.9(2.1)$ & $7.9(2.9)$ & $6.6(3.2)$ & $6.5(3.2)$ & $5.0(2.3)$ & $5.1(2.8)$ & $3.9(2.8)$ & $n=21 / 11$ \\
\hline Endoscopic index & $8.3(2.0)$ & & & $6.7(2.9)$ & & & $4.7(2.6)$ & $n=21 / 10$ \\
\hline No of patients treated & 21 & 21 & 20 & 19 & 14 & 13 & 11 & \\
\hline No of patients in remission & 0 & 2 & 5 & 6 & 4 & 6 & 7 & \\
\hline \multicolumn{9}{|l|}{ Placebo $(n=20)$} \\
\hline Rachmilewitz & $8.7(2.5)$ & $7.5(2.6)$ & $6.6(3.2)$ & $6.8(3.7)$ & $4.5(3.0)$ & $3.6(2.8)$ & $2.4(3.0)$ & $n=20 / 9$ \\
\hline Endoscopic index & $8.2(2.3)$ & & & $6.6(3.6)$ & & & $4.2(3.7)$ & $n=20 / 9$ \\
\hline No of patients treated & 20 & 20 & 20 & 18 & 12 & 10 & 9 & \\
\hline No of patients in remission & 0 & 3 & 3 & 7 & 7 & 7 & 7 & \\
\hline
\end{tabular}

leucocytes, with the most pronounced effects seen at PegIFN $1.0 \mu \mathrm{g} / \mathrm{kg}$. The higher PegIFN dose $(1.0 \mu \mathrm{g} / \mathrm{kg})$ was associated with a significant decrease in CRP levels $(\mathrm{p}=0.003$, day $0 v$ 85 ), which was not observed in the placebo or PegIFN $0.5 \mu \mathrm{g} /$ $\mathrm{kg}$ group (placebo $\mathrm{p}=0.606$, day $0 v 85$; PegIFN $0.5 \mu \mathrm{g} / \mathrm{kg}$ $\mathrm{p}=0.795$, day $0 \quad v$ 85). Neither treatment resulted in significant decreases in AGP levels up to day 85. However, decreases in both CRP and AGP were still significantly more pronounced in both PegIFN groups compared with placebo (table 4). Other laboratory parameters such as prothrombin time, bilirubin, total protein, and albumin levels did not change in either treatment group (placebo, PegIFN $0.5 \mu \mathrm{g} / \mathrm{kg}$, and PegIFN $1.0 \mu \mathrm{g} / \mathrm{kg}$ PegIFN; day $0 v 85$; data not shown).

\section{Follow up period}

This clinical trial included a follow up period of 26 weeks. Nine of 20 patients in the placebo group, 13/19 in the PegIFN $0.5 \mu \mathrm{g} / \mathrm{kg}$ group, and $11 / 21$ in the PegIFN $1.0 \mu \mathrm{g} / \mathrm{kg}$ group finished the 12 week treatment period and entered the follow up period. Remission at week $12(\mathrm{CAI} \leqslant 4)$ was found in $7 / 9$ patients in the placebo group, in $9 / 13$ in the PegIFN $0.5 \mu \mathrm{g} / \mathrm{kg}$ group, and in $7 / 11$ in the PegIFN $1.0 \mu \mathrm{g} / \mathrm{kg}$ group. Relapse (defined as initiation of steroid plus azathioprine treatment) was seen in $3 / 7$ (42\%) placebo patients, in 5/9 (55\%) patients in the PegIFN $0.5 \mu \mathrm{g} / \mathrm{kg}$ group, and in $2 / 7(28 \%)$ in the PegIFN $1.0 \mu \mathrm{g} / \mathrm{kg}$ group.

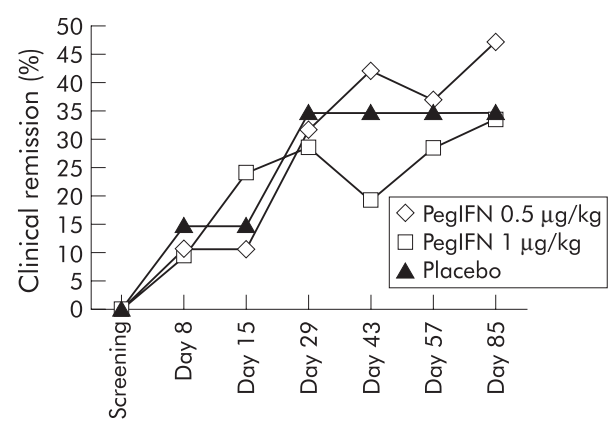

Figure 1 Clinical remission (in per cent) (clinical activity score of $<4$ ) in patients with active ulcerative colitis treated with placebo $(n=20)$, pegylated interferon $\alpha$ (PegIFN) $0.5 \mu \mathrm{g} / \mathrm{kg}(\mathrm{n}=19)$, or PegIFN $1.0 \mu \mathrm{g} / \mathrm{kg}$ $(n=21)$ over a 12 week treatment period.

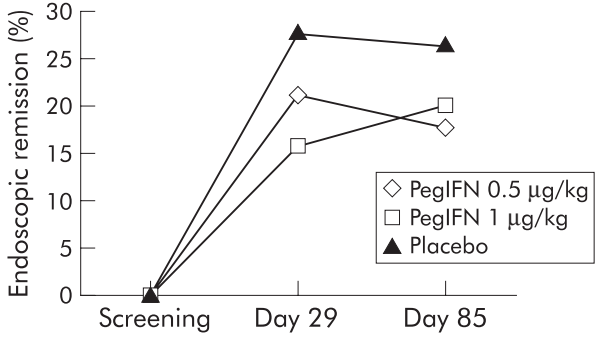

Figure 2 Endoscopic remission (defined as endoscopic activity $<4$ ) in patients treated with placebo, pegylated interferon $\alpha$ (PegIFN) $0.5 \mu \mathrm{g} /$ $\mathrm{kg}$, or PegIFN $1.0 \mu \mathrm{g} / \mathrm{kg}$ over a 12 week treatment period. Endoscopy was performed in the placebo group on day 0 in 19 , on day 29 in 14 , and on day 85 in 11 patients, in the PegIFN $0.5 \mu \mathrm{g} / \mathrm{kg}$ group on day 0 in 21 , on day 29 in 18, and on day 85 in 10 patients, and in the PegIFN $1.0 \mu \mathrm{g} / \mathrm{kg}$ group on day 0 in 20 , on day 29 in 18 , and on day 85 in nine patients.

\section{DISCUSSION}

UC affects variable portions of the colon, generally extending directly from the rectum. The main clinical characteristics of UC are the natural tendency to relapse with potential extension of disease and remission. ${ }^{12}$ Mediators of the immune system, including cytokines, arachidonic acid metabolites, reactive oxygen intermediates, and growth factors, are likely to play a role in the perpetuation and possibly the initiation of inflammation in these diseases and in their local (that is, fibrotic) and systemic complications. The relative balance of proinflammatory (that is, IL-1, TNF- $\alpha$ ) and anti-inflammatory (that is, IL-1Ra, transforming growth factor $\beta$, IL-6, IL-10) cytokines may determine the chronicity of inflammation and the tendency of reactivation and remission. ${ }^{3}$

Recently, data showed that Crohn's disease lamina propria cells manifest increased secretion of IFN- $\gamma$ whereas UC lamina propria cells manifest increased secretion of IL-5 and IL-13. ${ }^{11}{ }^{12}$ These data and previous data suggest that with respect to cytokine biology there may be differences between Crohn's disease and UC, supporting the concept that Crohn's disease is predominantly a Thl determined disease whereas UC is associated with a Th2 phenotype. ${ }^{311}{ }^{12}$ Side effects of IFN- $\alpha$ therapy and several clinical reports suggest that IFN- $\alpha$ may have proinflammatory effects in vivo. ${ }^{5}$ IFN- $\alpha$ is known to worsen several diseases linked to a Thl mediated pathophysiology such as psoriasis. On the other hand, 
Table 4 Laboratory parameters at screening examination and on day +85 of the study after treatment with placebo or pegylated interferon $\alpha$ (PegIFN)

\begin{tabular}{|c|c|c|c|c|}
\hline Placebo $(n=20)$ & Day 0 & & Day 85 & Patients day $0 / 85$ \\
\hline $\begin{array}{l}\text { Haemoglobin } \\
\text { Haematocrit } \\
\alpha_{1} \text { acid glycoprotein } \\
\text { C reactive protein } \\
\text { Erythrocytes } \\
\text { Leucocytes } \\
\text { Platelets }\end{array}$ & $\begin{array}{c}13.1(1.4) \\
39.3(4.0) \\
103.3(37.6) \\
1.4(1.3) \\
4.6(0.5) \\
8.7(3.8) \\
312.2(107.3)\end{array}$ & & $\begin{array}{c}13.3(0.9) \\
40.1(2.0) \\
80.5(21.2) \\
1.1(0.9) \\
4.7(0.4) \\
8.5(3.0) \\
314.7(74.8)\end{array}$ & $\begin{array}{l}\mathrm{n}=20 / 9 \\
\mathrm{n}=15 / 8 \\
\mathrm{n}=9 / 5 \\
\mathrm{n}=20 / 9 \\
\mathrm{n}=15 / 8 \\
\mathrm{n}=20 / 9 \\
\mathrm{n}=20 / 9\end{array}$ \\
\hline PegIFN $0.5 \mu \mathrm{g} / \mathrm{kg}(\mathrm{n}=19)$ & Day 0 & Day 85 & Patients day $0 / 85$ & PegIFN $0.5 \mu \mathrm{g} / \mathrm{kg} v$ placebo, day 85 \\
\hline $\begin{array}{l}\text { Haemoglobin } \\
\text { Haematocrit } \\
\alpha_{1} \text { acid glycoprotein } \\
\text { C reactive protein } \\
\text { Erythrocytes } \\
\text { Leucocytes } \\
\text { Platelets }\end{array}$ & $\begin{array}{c}13.6(1.5) \\
41.6(2.9) \\
100.4(29.7) \\
0.8(0.7) \\
4.8(0.4) \\
9.1(3.3) \\
342.1(141.7)\end{array}$ & $\begin{array}{c}12.7(1.7) \\
38.7(4.7) \\
86.8(18.6) \\
0.7(0.5) \\
4.7(0.6) \\
5.6(1.7) \\
286.2(90.0)\end{array}$ & $\begin{array}{l}n=18 / 13 \\
n=14 / 9 \\
n=9 / 6 \\
n=18 / 14 \\
n=14 / 9 \\
n=18 / 13 \\
n=18 / 13\end{array}$ & $\begin{array}{r}0.640 \\
0.113 \\
0.041 \\
<0.001 \\
0.006 \\
<0.001 \\
0.341\end{array}$ \\
\hline PegIFN $1 \mu \mathrm{g} / \mathrm{kg}(\mathbf{n}=21)$ & Day 0 & Day 85 & Patients day $0 / 85$ & PegIFN $1 \mu \mathrm{g} / \mathrm{kg} v$ placebo, day 85 \\
\hline $\begin{array}{l}\text { Haemoglobin } \\
\text { Haematocrit } \\
\alpha_{1} \text { acid glycoprotein } \\
\text { C reactive protein } \\
\text { Erythrocytes } \\
\text { Leucocytes } \\
\text { Platelets }\end{array}$ & $\begin{array}{c}13.0(1.8) \\
38.7(5.1) \\
125.9(39.9) \\
1.4(1.3) \\
4.4(0.6) \\
8.0(3.5) \\
308.1(116.6)\end{array}$ & $\begin{array}{c}11.1(1.9) \\
34.3(4.4) \\
111.0(28.3) \\
0.5(0.2) \\
4.4(0.5) \\
5.7(2.7) \\
302.3(151.4)\end{array}$ & $\begin{array}{l}N=18 / 13 \\
N=14 / 9 \\
N=9 / 6 \\
N=18 / 14 \\
N=14 / 9 \\
N=18 / 13 \\
N=18 / 14\end{array}$ & $\begin{array}{r}<0.001 \\
<0.001 \\
<0.001 \\
0.034 \\
0.005 \\
<0.001 \\
0.063\end{array}$ \\
\hline
\end{tabular}

IFN- $\alpha$ has beneficial effects in the treatment of diseases characterised by excess Th2 cells, such as early acquired immunodeficiency syndrome (AIDS), basal cell carcinoma, certain allergic diseases, and the hypereosinophilic syndrome. Taken together, these results indicate that IFN- $\alpha$ plays an important role in $\mathrm{T}$ cell differentiation towards a Thl type of immune response, which may be of importance in the treatment of viral infections and diseases dominated by a Th2 pathway such as UC. ${ }^{5} 6$

There is increasing evidence that IFN- $\alpha$ interferes with the synthesis of various proinflammatory cytokines such as IL- $1 .^{7}$ IFN- $\alpha$ and IFN- $\beta$ induce IL-1Ra, a cytokine which has been shown to reduce the severity of sepsis, arthritis, and colitis. ${ }^{17-}$ ${ }^{19}$ Furthermore, IFN- $\alpha$ suppresses IL- 8 in human fibroblasts. ${ }^{20}$ Several reports show that IFN- $\alpha$ may also suppress TNF- $\alpha$ gene expression and protein synthesis in vitro or in vivo. We demonstrated induction of circulating soluble TNFRp55 during IFN- $\alpha$ therapy, suppression of IL- $1 \alpha$ induced TNF- $\alpha$ synthesis in vitro by PBMC from healthy volunteers, and induction of IL-18 binding protein, the physiological IL-18 antagonist, in hepatitis $\mathrm{C}$ patients undergoing IFN- $\alpha$ therapy. ${ }^{81}$ In addition, IFN- $\alpha$ induces IL-10 in human PBMC. ${ }^{22}$ All of these biological effects could contribute to the antiinflammatory effects of IFN- $\alpha$.

As IFN- $\alpha$ suppresses the synthesis of proinflammatory cytokines, induces various anti-inflammatory cytokines, and regulates important immunoregulatory cytokines, IFN- $\alpha$ may be effective in non-viral diseases of the gastrointestinal tract. Preliminary results suggested that IFN $-\alpha$ therapy may be effective in Crohn's disease, although a report in steroid dependent patients showed no benefit of IFN- $\alpha$ therapy. ${ }^{23}$ This may be explained by the fact that Crohn's disease is thought to be a Thl linked disease. IFN- $\alpha$ therapy seemed to be more successful in active UC. Sumer and Palabiyikoglu reported that more than $80 \%$ of patients with active UC responded to high dose IFN- $\alpha$ therapy within two weeks of treatment (starting dose of 9 million units three times weekly) and were in complete clinical and endoscopic remission after six months of therapy. ${ }^{13}$ Twenty six of 28
IFN treated patients were observed for more than two years without being given therapy and remained in full clinical and endoscopic remission. Madsen et al recently presented a study comparing systemic IFN- $\alpha$ therapy and prednisolone enemas in the treatment of left sided ulcerative colitis. In their study, the authors used high doses of conventional IFN- $\alpha$ (a starting dose of 9 million units three times weekly) and observed a significant improvement in disease activity with IFN- $\alpha$ therapy, including histological improvement within 24 weeks. ${ }^{14}$ IFN- $\beta$ has been used in a pilot study investigating its role in patients with steroid refractory active UC. ${ }^{24}$ In this study, a high responder rate was also observed (22/25 patients; $88 \%$ ) with a mean time to response of three weeks. Both IFN- $\alpha$ and IFN- $\beta$ share an identical cellular surface receptor $^{25}$ and therefore are expected to exert similar biological effects. It has been demonstrated that both IFNs induce similar genes in human endothelial cells but higher concentrations of IFN- $\alpha$ compared with IFN- $\beta$ were necessary to activate identical genes. ${ }^{26}$

We now present data about the first placebo controlled use of IFN- $\alpha$ in the treatment of active UC in patients with or without corticosteroid and/or immunosuppressive treatment. IFN- $\alpha$ doses used in pilot studies in UC (9 million units of conventional IFN three times weekly) ${ }^{13}{ }^{14}$ cannot be translated easily into doses of the pegylated forms (expressed in terms of micrograms of PegIFN) as used in our study (PegIFN $1.0 \mu \mathrm{g} / \mathrm{kg}$ reflects approximately 3 million units IFN $\alpha$-2b three times weekly). In contrast with published pilot studies, ${ }^{13}{ }^{14}$ we also included almost $50 \%$ of patients treated with steroids/immunosuppressants. We observed no significant advantage of any PegIFN group over placebo. Interestingly, we did not reach a plateau phase of remission rates in either PegIFN group over our 12 week treatment period, suggesting that longer treatment may be necessary. In our study, we also observed only a weak correlation between clinical indices and endoscopic scores and PegIFN did not lead to endoscopic or histological improvement. PegIFN treatment was associated with a more pronounced reduction in inflammatory parameters such as CRP and AGP and also 
with more side effects compared with placebo. The effects on acute phase reactants may suggest some in vivo antiinflammatory activity, especially with the higher PegIFN dose, but these effects were not sufficient to improve disease activity parameters, such as CAI or endoscopic findings.

Our data suggest that IFN- $\alpha$ therapy, at the low doses used, was safe but not effective in the treatment of UC compared with placebo. Further clinical trials in active UC should investigate higher doses of IFN- $\alpha$ which have been shown to be effective in pilot studies. ${ }^{13}{ }^{14}$ In addition, it may be worth testing whether low atoxic doses of IFN- $\alpha$ can maintain remission in this chronic relapsing disorder.

\section{ACKNOWLEDGEMENTS}

This study was supported by Schering-Plough, Kenilworth, USA, and by the Austrian Science Fund (FWF) (P1464l and P15783 to HT).

\section{Authors' affiliations}

H Tilg, O Ludwiczek, A Kaser, H Ulmer, Department of Gastroenterology and Hepatology and Biostatistics, University Hospital Innsbruck, Austria

H Vogelsang, M Harrer, C Gasche, W Reinisch, Department of Gastroenterology, University Hospital Vienna, Austria

H Lochs, S Krüger, Department of Gastroenterology, Charite, Berlin, Germany

J-F Colombel, A Cortot, Department of Gastroenterology, Lille, France

P Rutgeerts, G D'Haens, Department of Gastroenterology, UZ

Gasthuisberg, Leuven, Belgium

F Wrba, Department of Pathology, University Hospital Vienna, Austria

I Kuhn, AESCA GmbH, Traiskirchen, Austria

\section{REFERENCES}

1 Farrel RJ, Peppercorn MA. Ulcerative colitis. Lancet 2003;359:331-40

2 Podolsky DK. Inflammatory bowel disease. N Engl J Med 2002;347:417-29.

3 Fiocchi C. Inflammatory bowel disease: etiology and pathogenesis. Gastroenterology 1998;115:182-205

4 Sadlack B, Merz H, Schorle $\mathrm{H}$, et al. Ulcerative colitis-like disease in mice with a disrupted interleukin-2 gene. Cell 1993;75:253-61.

5 Tilg $\mathbf{H}$. New insights into the mechanisms of interferon alfa: An immunoregulatory and anti-inflammatory cytokine. Gastroenterology 1997:112:1017-21.

6 Guttermann JU. Cytokine therapeutics: Lessons from interferon alpha. Proc Natl Acad Sci U S A 1995;91:1198-205.

7 Tilg H, Mier JW, Vogel W, et al. Induction of circulating IL-1 receptor antagonist by IFN treatment. J Immunol 1993;150:4687-92.

8 Tilg H, Vogel W, Dinarello CA. Interferon-alpha induces circulating tumor necrosis factor receptor p55 in humans. Blood 1995;85:433-5.
9 Schandené L, Del Prete GF, Cogan E, et al. Recombinant interferon-alpha selectively inhibits the production of interleukin- 5 by human CD $4+T$ cells. J Clin Invest 1996;97:309-15.

10 Kaser A, Molnar C, Tilg H. Differential regulation of interleukin 4 and interleukin 13 production by interferon-alpha. Cytokine 1998;10:75-81.

11 Fuss IJ, Neurath M, Boirivant M, et al. Disparate CD4+ lamina propria (LP) lymphokine secretion profiles in inflammatory bowel disease: Crohn's disease LP cells manifest increased secretion of IFN-gamma, whereas ulcerative colitis LP cells manifest increased secretion of IL-5. J Immunol 1996;157:1261-70.

12 Heller F, Boirivant M, Mannon P, et al. IL-13 secretion by CD4 $4^{+} C D 161^{+}$NK-T cells is increased in oxazolone and human ulcerative colitis (UC). Gastroenterology 2003; 124:A35, (abstract 276).

13 Sumer N, Palabiyikoglu M. Induction of remission by interferon-alpha in patients with chronic active ulcerative colitis. Eur J Gastroenterol Hepatol 1995;7:597-602

14 Madsen SM, Schlichting P, Davidsen P, et al. An open-labeled, randomized study comparing systemic interferon-alpha-2A and prednisolone enemas in the treatment of left-sided ulcerative colitis. Am J Gastroenterol 2001:96:1807-15.

15 Rachmilewitz D. Coated mesalazine (5-aminosalicyclic acid) versus sulphasalazine in the treatment of active ulcerative colitis: a randomised trial. BMJ 1989;298:82-6.

16 Hanaver SB, Robinson M, Pruitt R, et al. Budesonide enema for the treatment of active, distal ulcerative colitis and proctitis: A dose-ranging study. Gastroenterology 1998;115:525-32.

17 Dinarello CA. Biologic basis for interleukin-1 in disease. Blood 1996:87:2095-147.

18 Schindler R, Ghezzi P, Dinarello CA. IL-1 induces IL-1. IV. IFN-gamma suppresses IL-1 but not lipopolysaccharide-induced transcription of IL-1. J Immunol 1990;144:2216-22.

19 Huang $Y$, Blatt $L M$, Tylor MW. Type I interferon as an antiinflammatory agent: Inhibition of lipopolysaccharide-induced interleukin-1 beta and induction of interleukin-1 receptor antagonist. J Interferon Cytokine Res 1995;15:317-21.

20 Oliviera IC, Scuavolino PJ, Lee TH, et al. Downregulation of interleukin- 8 gene expression in human fibroblasts: Unique mechanism of transcriptional inhibition by interferon. Proc Natl Acad Sci U S A 1992;89:9043-8.

21 Kaser A, Novick D, Rubinstein M, et al. Interferon-alpha induces interleukin18 binding protein in chronic hepatitis $C$ patients. Clin Exp Immunol 2002:129:332-8.

22 Amann MJ, Tretter T, Eisenbeis I, et al. Interferon-alpha stimulates production of interleukin-10 in activated CD4+ T cells and monocytes. Blood 1996:87:4731-6.

23 Gasche C, Reinisch W, Vogelsang H, et al. Prospective evaluation of interferon-alpha in treatment of chronic active Crohn's disease. Dig Dis Sci 1995;40:800-4.

24 Musch E, Andus T, Malek M. Induction and maintenance of clinical remission by interferon beta in patients with steroid-refractory active ulcerative colitis: an open long-term pilot trial. Aliment Pharmacol Ther 2002;16:1233-9.

25 Novick D, Cohen B, Rubinstein M. The human interferon alpha/beta receptor: characterization and molecular cloning. Cell 1994:77:391-400.

26 da Silva AJ, Brickelmaier M, Majeau GR, et al. Comparison of gene expression patterns induced by treatment of human umbilical vein endothelial cells with IFN-alpha $2 b$ versus IFN-beta la: understanding the functional relationship between distinct type I interferons that act through a common receptor. J Interferon Cytokine Res 2002;22:173-88. 